\title{
KRITIK KARL MARX TERHADAP KAPITALISME DAN PENGERTIAN EKONOMI SOSIALISME
}

Oleh:

\author{
Nurul Wahida Aprilya (90100118110) \\ Fakultas Ekonomi dan Bisnis Islam UIN Alauddin Makassar \\ e-mail: wahidaprilya@gmail.com
}

\section{A. Kritik Karl Marx Terhadap Kapitalisme}

Karl Marx merupakan seorang filsuf, ekonom, sejarawan, pembuat teori politik, sosiolog, jurnalis dan sosialis revolusioner asal Jerman. Beberapa pemikirannya sangat revolusioner sehingga mampu merubah sejarah. Beberapa peristiwa dunia seperti revolusi Rusia, revolusi China dan beberapa negara asia lainnya baik langsung maupun tidak langsung terispirasi dari pemikran Karl Marx. ${ }^{1}$ Marx lahir dengan nama Karl Heinrich Marx, sebagai pencetus aliran filsafat marxisme ini lahir pada 5 mei 1818 di kota Trier-Rusia sebelah perbatasan barat Jerman. Ia dilahirkan ditengah-tengah keluarga Yahudi. $^{2}$

Berbicara tentang kapitalisme seolah tak mungkin untuk mengabaikan Adam Smith. Adam smith merupakan pemikir pertama yang mengembangkan pentingnya Akumulasi Kapital dalam pengembangan ekonomi. Teori Adam Smith tentang Labour Theory of Value itu kemudian menjadi dasar kapitalisme. ${ }^{3}$ Ernest mandel dalam buku Bagong Suyanto yang berjudul "Sosiologi Ekonomi: Kapitalisme dan Konsunsi di Era

${ }^{1}$ Yohanes Bahari, "Karl Marx: Sekelumit Tentang Hidup dan Pemikirannya," Jurnal Pendidikan Sosiologi dan Humaniora, Vol.1 No. 10, 2010. h. 9

2 Kambali, M, "Pemikiran Karl Marx Tentang Struktur Masyarakat (Dialektika Infrastruktur dan Suprastruktur)," Jurnal Pemikiran dan Penelitian Ekonomi Islam, Vol. 8 No. 2 , 2020, h. 65

${ }^{3}$ Kartini, Mulawan, \& Yuningsih, "Kapitalisme Pedesaan Di Kawasan Ekonomi Khusus (KE) Tanjung Lesung Kabupaten Pandeglang Propinsi Banten," CosmoGov: Jurnal Ilmu Pemerintahan, Vol. 3 No. 1, 2017. h. 57 
Masyrakat Post Modernisme" membahs lebih perinci dan mengajukan lima ciri pokok dari ekonomi kapitalisme. Pertama, ditingkat produksi, corak kapitalis adalah produksi komoditas, untuk meraih keuntungan yang sebesar-besarnya. Kedua, produksi dilandasi kepemilikan pribadi. Ketiga, produksi dioperasinalkan dalam rangka meraih menguasai pasar yang berada dibawah kendali persaingan. Keempat para kapitalis beupaya merauk keuntungan yang sebesar-besarnya dengan cara melakukan. Kelima, tujuan terakhir dari produksi adalah akumulasi kapital. ${ }^{4}$

Kapitalisme adalah sistem ekonomi yang dimana kegiatan ekonominya dilakukan sesuai dengan mekanisme pasar dan campur tangan pemerintah sangat minim. Setiap individu kapitalisme mempunyai kebebasan penuh dalam melakukan kegiatan yang memberikan keuntungan bagi dirinya. Menurut Adam Smith pasar bebas akan memberikan keuntungan bagi semua orang, tapi menurut Karl Marx itu tidak. Nah disinilah munculnya kritik Karl Marx terhadap kapitalisme. Ia mengatakan bahwa pasar bebas ini akan menimbulkan konsekuensi yang sangat negatif bagi masyrakat, yaitu melebarnya kesenjangan sosial. Jadi pasar bebas ini hanya akan menguntungkan kaum borjuis atau para pemegang alat produksi ataupun para pemilik modal itu menjadi kaya makin lebih kaya lagi, sedangkan para pekerja atau buruh itu sangat dirugikan dengan mekanisme pasar bebas ini.

Karl marx merupakan salah satu penentang ekonomi kapitalis. Pada tahun 1867, dimana kapitalisme sedang tumbuh dan berkembang, Marx menulis sebuah karya ilmiah mengenai kritik terhadap kapitalisme yang dijadikan buku yaitu Das Kapital. Yang dimana dalam buku tersebut Ia membahas tentang bagaimana kapitalisme bekerja dengan cara mengeksploitasi buruh-buruh, baik itu perempuan, laki-laki maupun anak-

${ }^{4}$ Sirajuddin \& Tamsir, "Rekonstruksi Konseptual Kepemilikan Harta Perspektif Ekonomi Islam (Studi Kritis Kepemilikan Harta Sistem Ekonomi Kapitalisme)," Laa Maisyir: Jurnal Ekonomi Islam, Vol.6 No.2, 2019. h. 213. 
anak. ${ }^{5}$ Buku Das Kapital diharapkan sebagai senjata teoritis bagi kaum buruh dalam perjuangan merebut kesejahteraan yang telah diambil oleh kaum kapitalis. Banyak para ahli ekonomi mempertanyakan keberhasilan Karl Marx dalam membela kaum buruh, mereka berpendapat teori Karl Marx runtuh bersama runtuhnya tembok Berlin dan jatuhnya Negara Uni Soviet sebagai basis sistem sosialis. ${ }^{6}$

\section{B. Pengertian Ekonomi Sosialisme}

Sistem ekonomi sosialis mulai diutarakan oleh Karl Marx dalam bukunya Das Kapital. Ini merupakan satu kritikan kepada sistem ekonomi kapitalis yang dikatakan telah gagal mewujudkan sebuah sistem ekonomi yang stabil. ${ }^{7}$ Menurut Karl Marx, manusia itu merupakan makhluk sosial maka dari itu aktivitas ekonomi tidak boleh dikuasi oleh individu tapi harus dikelola bersama-sama yang diatur oleh negara. Jadi marx ini memperkenalkan sosialisme sebagai sistem ekonomi terpusat dimana pemerintah memegang peranan paling penting atau dominan dalam pengaturan kegiatan ekonomi.

Sistem ekonomi sosialis merupakan kebalikan dari sistem ekonomi kapitalis. Sosialisme merupakan sistem ekonomi yang dimana segala kagiatan ekonominya diatur oleh pemerintah dan perencanan terpusat dari pemerintah. Pengertian sosialisme ini sangat benbanding balik dari kapitalisme, dimana sistem perekonomiannya memberikan kebebasan secara penuh kepada setiap orang untuk melaksanakan kegiatan perekonomian.

${ }^{5}$ Moh. Nurul Qomar, "Kritik Marx Terhadap Konsep Buruh Kapitalis Kajian Komparatif Ekonomi Syariah Atas Buku Das Kapital," In Proccedings of Annual Conference for Muslim Scholars, Vol. 3 No. 1, 2019. h. 1004.

${ }^{6}$ Karl Marx, Kapital Sebuah Kritik Ekonomi Politik. (Jakarta: Hasta Mitra, 2004), h. 17.

${ }^{7}$ Boy Syamsul Bakhari, "Sistem Ekonomi Islam dalam Perbandingan," Jurnal Agama dan Ilmu Pengetahuan, Vol. 8 No. 1, 2011. h. 44 
Sistem ekonomi sosialis bukan berarti tidak memberikan kebebasan individu dalam kegiatan ekonomi, melainkan tiap individu itu masih tetap diberikan kebesan dalam melakukan aktivitas ekonomi tetapi sangat terbatas sekali, karena adanya campur tangan pemerintah yang sangat besar. Pemerintah melakukan campur tangan demi terwujudnya kemakmuran masyarakat bersama, tetapi di sisi lain kepemilikan individu yang dibatasi menyebabkan kreativitas individu semakin menurun karena semangat untuk berkarya di bayang-bayangi oleh pemerintah untuk kemakmuran bersama. ${ }^{8}$

\footnotetext{
${ }^{8}$ Muhammad Tho'in, “Konsep Ekonomi Islam Jalan Tengah (Kapitalis-Sosialis),” Jurnal
} Ilmiah Ekonomi Islam, Vol. 1 No. 03, 2015. h. 125 


\section{DAFTAR PUSTAKA}

Bakhri, B. S. (2011). Sistem Ekonomi Islam dalam Perbandingan. Al-Hikmah: Jurnal Agama dan Ilmu Pengetahuan, 8(1), 42-49.

Bahari, Y. (2010). Karl Marx: Sekelumit Tentang Hidup dan Pemikirannya. Jurnal Pendidikan Sosiologi dan Humaniora, 1(10).

Kambali, M. (2020). Pemikiran Karl Marx Tentang Struktur Masyarakat (Dialektika Infrastruktur dan Suprastruktur). Jurnal Pemikiran dan Penelitian Ekonomi Islam, $8(2), 63-80$.

Kartini, D. S., Mulawan, R., \& Yuningsih, N. Y. (2017) "Kapitalisme Pedesaan Di Kawasan Ekonomi Khusus (KE) Tanjung Lesung Kabupaten Pandeglang Propinsi Banten," CosmoGov: Jurnal Ilmu Pemerintahan, 3(1), 55-64.

Marx, K. (2004). Kapital Sebuah Kritik Ekonomi Politik. (Jakarta: Hasta Mitra).

Qomar, M. N. (2019) “Kritik Marx Terhadap Konsep Buruh Kapitalis Kajian Komparatif Ekonomi Syariah Atas Buku Das Kapital,” In Proccedings of Annual Conference for Muslim Scholars, 3(1), 1003-1009.

Sirajuddin, S., \& Tamsir, T. (2019). Rekonstruksi Konseptual Kepemilikan Harta Perspektif Ekonomi Islam (Studi Kritis Kepemilikan Harta Sistem Ekonomi Kapitalisme), Laa Maisyir: Jurnal Ekonomi Islam, 6(2), 211-225.

Tho'in M. (2015). Konsep Ekonomi Islam Jalan Tengah (Kapitalis-Sosialis). Jurnal Ilmiah Ekonomi Islam, 1(03). 